\title{
Water Woes in Zimbabwe's Urban Areas in the Middist Of Plenty: 2000 -Present
}

\author{
Enock C.Makwara ${ }^{1}$ and Baxter Tavuyanago ${ }^{1}$
}

\section{Abstract}

Zimbabwe's urban areas are choking under the weight of over-crowdedness amidst dilapidated infrastructure that is characterised by constant service failure. The water and sewer systems of the country's major urban centres are on the verge of collapse, thus putting millions of people in danger of consuming contaminated water, including that from underground sources. Waste management and water supply problems manifest themselves as challenges bedevilling many an urban area in the country. The quality and quantity of water supplied in Zimbabwe's urban centres has plummeted in recent years and has assumed crisis proportions owing to the difficult economic situation and other challenges faced by the country. The situation is desperate and dire, as is evidenced by the poor quality of delivered water, severe water rationing and the outbreak of water-borne diseases in the urban areas dotted across the country. The situation demands and dictates that solutions be proffered as a matter of urgency.The recent outbreak of epidemics has been blamed on lack of access to safe water and poor sanitation, two crucial factors in controlling the spread of diseases. An overly bureaucratic environment, where decisions and processes take longer, makes life complicated for poor urban residents. Such a scenario motivated the researchers to examine the problem with a view to suggest ways and means of intervening to mitigate and resolve the problem. It emerged from the findings that the problem is multifaceted in nature, hence a whole range of measures need to be adopted if a long-term solution is to be provided.

Keywords: Domestic Water Shortage; Water Treatment, Access to Safe Water, Sanitation, Towns /Cities/ Urban Centres, Zimbabwe

\subsection{Introduction}

\subsection{Background and importance of the study}

Southern Africa in general and Zimbabwe in particular has been experiencing critical and debilitating water shortages in its urban settlements since the

| ${ }^{1}$ Lecturer in Geography at Great Zimbabwe University, Curriculum Studies Department. E-mail: enomakwara@yahoo.com Mobile; +263 0712867194/263

0773898758/+263734127836

2 Lecturer in History and Development Studies Department Studies at Great Zimbabwe University. E-mail:baxterkov@gmail.com Mobile; +263 775130410 
beginning of this millennium. Water shortages have been reported even when normal to above normal rainy seasons would have been experienced (The Chronicle, 2012). Water sources might be full yet paradoxically severe water shortages continue to haunt most of Zimbabwe's urban centres. Issues arising from such a scenario are many and varied. Issues like the causes, magnitude, impact of the problem and the way forward to resolve the problem, immediately come to mind. The study thus sought to address these challenges in so far as water provision is concerned in an endeavour to proffer sustainable solutions to this now perennial problem in many towns.

The situation has resulted in the transmission of such communicable diseases as cholera, diarrhoea, dysentery and most recently typhoid, easily preventable diseases which have wreaked havoc in the country. Because of the relatively porous borders and the ease movement of people between countries of the region, these diseases have been imported and exported between countries, notably towns, destinations of many migrants from all corners of respective countries and beyond.

\subsection{The Thirst Grows}

Discernible urbanization in Zimbabwe followed the creation of separate development areas [European and African] in the 1930s with towns and cities being established in European areas (Chaeruka and Munzwa, 2009). The political economy of the time meant that Europeans were regarded as the 'genuine' and permanent residents of towns and cities. Since blacks were regarded as 'visitors' their service needs were not significantly provided for. Today, Zimbabwe's urban settlements encounter several constraints in the delivery of services such as provision of power, water, sewage and waste management. Undoubtedly, water is the lifeblood of the biosphere. Access to this fugitive, finite, vital yet vulnerable resource in its safe form is limited. As population multiplies, the amount of water used by society escalates and thus 'the thirst grows'.

Water resources have been, are and continue to be controlled by a range of stakeholders. These include local and national government and private individuals. The fact that water is controlled means that it has economic as well as social value. Its being valuable suggests that it is subject to control implies that access to it could be restricted or denied completely. Some groups of people suffer as a result of water scarcity while others benefit yet clean, safe drinking water is an absolute necessity from both economic and social standpoints.

Since the late 1990s, an increasing number of urban areas in Zimbabwe have been haunted by water problems. This has been attributed to poor rainfall, insufficiently trained water resources personnel, population growth, aging infrastructure, lack of funds, and corruption. (The Herald,2011, The Chronicle, 
2012; Rondinelli, 1991; Chatora, Taylor and Hoevenaars, 1995, Mpande \&Tawanda, 1998; Nel \& Barry, 1992). All of Zimbabwe's major urban centres, among them Greater Harare (Harare,Chitungwiza,Norton,Epworth and Ruwa), Bulawayo, Mutate, Gweru ,Masvingo and Kadoma are plagued by an inadequate water supplies (The Standard, 2010; The Herald, 2010;Dube and van der Zaag,2002; Gumbo and van der Zaag, 2001;Nhlanhla, 2008; Reuters, 2007; Nel \& Berry, 1992). The problem is compounded by the fact that sanitation and hygiene have fallen to lowly levels in most parts of the country including its more developed areas, the urban centres. Such a scenario is not peculiar and unique to Zimbabwe. Urbanization is increasing at the fastest rate in sub-Saharan Africa.

\subsection{Objectives of the study}

This study was motivated by the recognition of a failed water delivery service bedevilling Zimbabwe's urban areas since the beginning of the millennium. Reports and discussions on numerous towns within the country and region, also facing water problems underscored the desire to conduct this study. This paper examines the causes and impacts of domestic water shortages in Zimbabwe's urban centres. The primary objective of the study was to analyse current water delivery problems with the aim of identifying challenges and shortcomings therein. Results of the analysis should be discussed with relevant stakeholders to build consensus and options in the development and delivery of water. Specific objectives of the research were to:

identify challenges in the urban water delivery system for the development of sustainable water delivery ;

examine the water delivery service problems[processes and procedures] and synthesize, document and disseminate relevant recommendations from the above processes to relevant stakeholders.

\subsection{Study methodology and activities}

The study was conducted from December 2008 to February, 2012, and was qualitative in nature as it was a general survey of water supply and provision in Zimbabwe's urban centres. It is basically a desktop study, mainly relying on documentary analysis though interviews were conducted and observations were made during the survey to establish information regarding population growth, ageing equipment and lack of resources both material and financial. Such an historical analysis enabled clear identification of some of the causes of the water delivery problems and the magnitude of their impact over time, while also highlighting innovative approaches adopted this far. These sources were mainly newspaper and published articles written about the water situation in the country's 
urban areas. A lot has been written on the problem of the water shortages in Zimbabwe's urban areas so the researchers sought to get first hand information on the situation on the ground and why the problem is persisting and eluding resolution. Two integrated methods were used in a generally analytical framework. The first was review-analysis of available literature of relevance to the subject. This involved published and grey literature. The second involved engaging with the lived experiences of personnel in the water supply sector and ordinary citizens. Six urban councils were roped in the study. Specific primary data gathering instruments used included structured and semi-structured interview guides and observation schedules.

Interviews were conducted with key informants for example policy makers and planners in municipal councils and the Zimbabwe National Water Authority (ZINWA), a quasi -government agency tasked with the provision of water and sewerage reticulation. These were conducted to solicit and elicit residents' perception of the problem as well as to determine the gravity of this manifest problem. Such information was corroborated by observatory evidence drawn from towns and cities identified as case

studies. This way, environmental impacts of water shortages were also identified and explored, and proposals for mitigating the situation were proffered.

\subsection{Study area}

Figure 1: Zimbabwe's major cities and towns

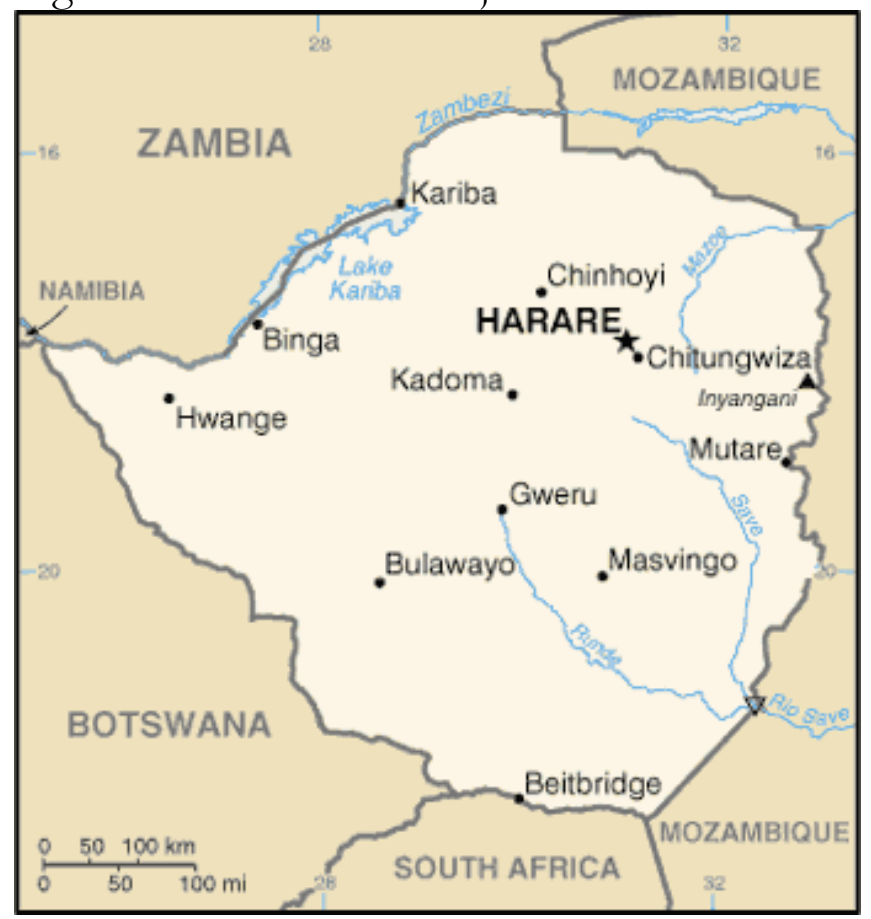

Source:http://geography.about.com/od/findmaps/ig/Country-Maps/Zimbabwe-Map.htm 
Zimbabwe's urban centres (Fig 1), have experienced phenomenal growth since independence in 1980. These centres are now home to no less than forty percent of the country's population (Central Statistical Office 2002, Population Reference Bureau, 2011). As it was practically impossible to study all of the country's urban centres, only a few, spanning the breadth and length of the entire country, were randomly sampled from among the numerous urban centres [See Figure 1]. The findings obtained were generalized to all the other urban centres. The table below is a summary of the major water supply dams to the respectively named urban centres.

Table 1: Major urban water supply dams in Zimbabwe

\begin{tabular}{|l|l|l|l|l|c|}
\hline Name & River & $\begin{array}{l}\text { Year of } \\
\text { construction }\end{array}$ & Purpose & $\begin{array}{l}\text { Town/City } \\
\text { supplied }\end{array}$ & $\begin{array}{l}\text { Capacity in } \\
\text { million m3. }\end{array}$ \\
\hline Mutirikwi (Kyle) & Mutirikwi & 1961 & $\begin{array}{l}\text { Irrigation\&water } \\
\text { supply }\end{array}$ & Masvingo & 1425 \\
\hline $\begin{array}{l}\text { Darwendale } \\
\text { Robertson)) }\end{array}$ & Hunyani & 1976 & Water supply & $\begin{array}{l}\text { Greater } \\
\text { Harare }\end{array}$ & 490 \\
\hline $\begin{array}{l}\text { Hunyani } \\
\text { Poort(McIlwaine) }\end{array}$ & Hunyani & 1952 & Water supply & $\begin{array}{l}\text { Greater } \\
\text { Harare }\end{array}$ & 250 \\
\hline Mayfair & Insiza & 1976 & Water supply & Bulawayo & 182 \\
\hline Sebakwe & Sebakwe & 1957 & Water supply & Kwekwe & 154 \\
\hline Inyankuni & Inyankuni & 1964 & Water supply & Bulawayo & 82 \\
\hline Umzingwane & Umzingwani & 1958 & Water supply & Bulawayo & 57 \\
\hline Ncema Upper & Ncema & 1973 & Water supply & Bulawayo & 45 \\
\hline Gwenoro & Lundi & 1958 & $\begin{array}{l}\text { Irrigation } \\
\text { \&water supply }\end{array}$ & Gweru & 32 \\
\hline Ncema & Ncema & 1943 & Water supply & Bulawayo & 18 \\
\hline Odzani & Odzani & 1965 & Water supply & Mutare & 6 \\
\hline
\end{tabular}

Source: Adapted from House and Salt, 1983

\subsection{Findings and discussion}

\subsection{Service provision status}

A myriad of acutely serious issues arose from the research. Urban local authorities are grappling with the outbreak of water-borne diseases particularly cholera, typhoid, dysentery and diarrhoea. It emerged that service delivery in Zimbabwe has overall fallen to unacceptable levels. Indeed it is at best in the intensive care unit. Larger urban centres are hardest hit. The outbreak of cholera (mid 2008-mid 2009) and typhoid (late 2011to present) in Harare got amplified nationwide. The outbreaks have been attributed to the disintegration of 
sewer systems, poor sanitation in the cities' high density suburbs, bad policies, the decline and subsequent collapse of health services and contaminated water most of which is drawn from unprotected sources and is by and large consumed raw. The typhoid outbreak comes four years after cholera played havoc with the lives of thousands of people also in Greater Harare, Beit Bridge and Kadoma in particular and in one or two other urban centres. The cholera epidemic engulfed and literally set Zimbabwe ablaze, with the disease ravaging almost the entire country. During Zimbabwe's last and worst cholera epidemic between August 2008 and July, 2009,[regarded as the worst in Africa ] over 4000 people needlessly lost their lives out of the more than 100000 infections before it was brought under control (http://www.zimonline.co.za ,29 February 2012). The epicentre of this catastrophe indeed, humanitarian crisis were the urban centres which were and still are hard hit by the manifestly acute water shortages when the country imploded under the economic meltdown (2007-2009).Plate 1 vividly summarises the desperate water shortage situation in a Harare suburb.

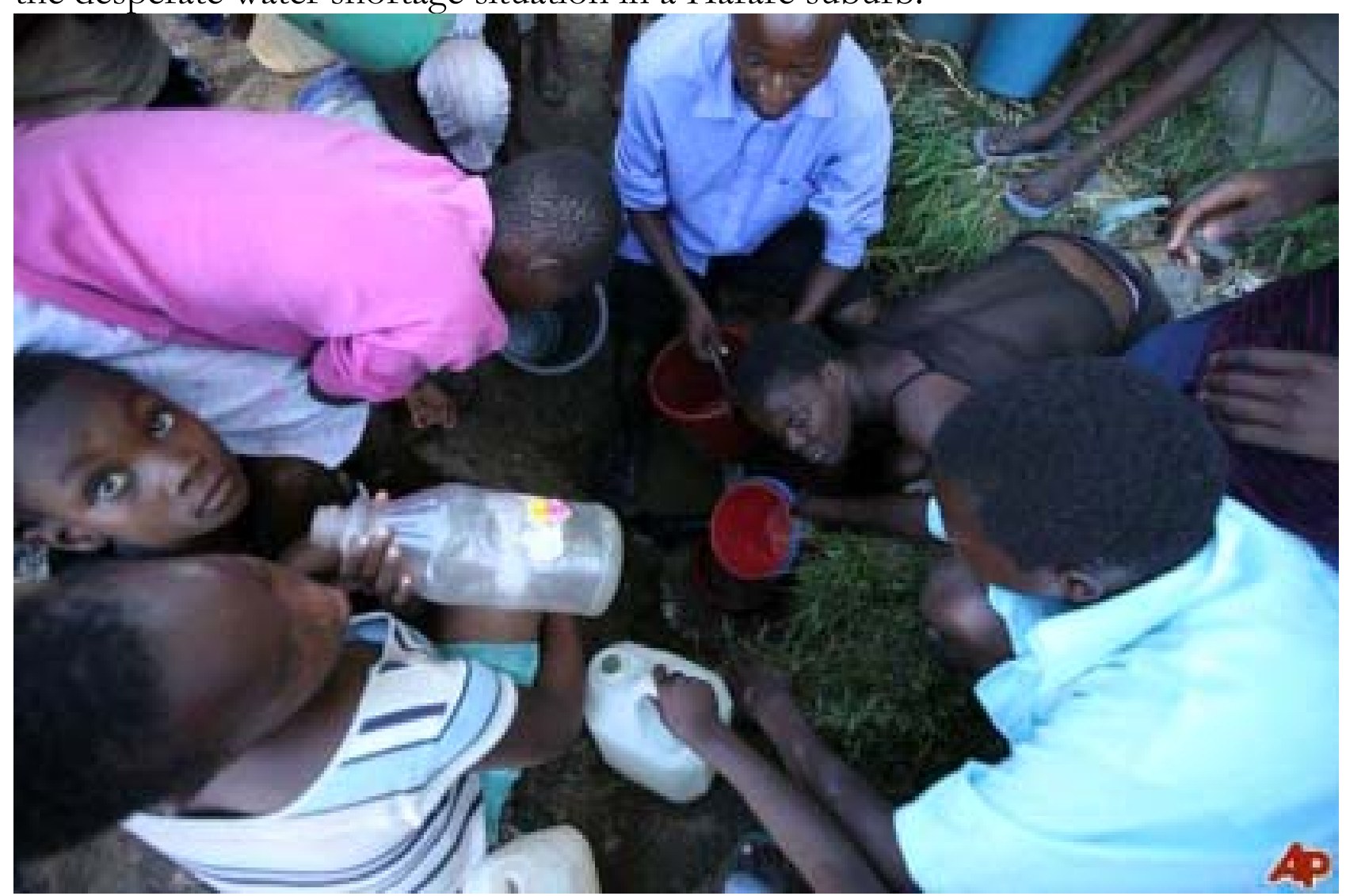

Plate 1: Residents scrambling for water. Source: The Zimbabwean, 24 February, 2012

Such a scenario became the norm in the country's urban centres. The first cases of typhoid were reported in Harare last October, with city officials blaming the outbreak on contaminated food sold in the open in the capital's low-income 
suburbs. Residents however blame councils for the outbreak of the otherwise preventable diseases accusing them of not prioritising water and sanitation services. They argue that poor hygiene and sanitation have caused numerous disease outbreaks in Zimbabwe in recent years. Some suburbs go for weeks or months on end, without running water as Zimbabwean municipalities struggle to keep up services. Last October, more than 6,000 cases of diarrhoea were reported in the southern towns of Masvingo and Kadoma and children were the worst affected. Two deaths have already been reported in Harare following a typhoid outbreak which started late last year, while over 3000 people have presented typhoid symptoms at various clinics as the disease threatens to engulf the country yet the ministry does not have the capacity to combat a major typhoid outbreak(http://www.zimonline.co.za,29

February,2012;www.voanews.com/Zimbabwe/news/14

February,2012;http://www.dailynews.zw ,24 February,2012)

Once there is an outbreak, diseases spread to other parts because the environment would be conducive for that. Water supply remains erratic, sewer bursts are still common while refuse collection is not being done on a regular basis. Consequently, there has been an upsurge in common diarrhoeal diseases largely due to poor sanitation and the continuing failure by towns and cities to provide clean water and manage sewage treatment and garbage collection.

There are fears of a cholera outbreak with many of the UNICEF boreholes drying up or being dysfunctional due to overuse.(The Chronicle,11 February,2011).Most of the suburbs hit by the diseases have long been without water, a fact acknowledged by both municipalities and ZINWA who said they could not supply water to all the residents. Although cholera and typhoid infection and mortality have declined recently, there is a looming potential for the recurrence of the epidemics.

\subsection{Ageing water treatment and supply infrastructure}

Water treatment plants have become obsolete. They were commissioned in the late 1930s to the 1950s if not earlier. (Mangizvo\&Kapungu, 2010; The Chronicle; 2012 \&The Herald, 2012). Dams and water treatment and supply facilities date back to before independence in 1980 (www.voanews.com/zimbabwe/news/14February,2012). Over the years, the plants have undergone a series of upgrades, albeit cosmetic. Sadly, these upgrades do not seem to be keeping pace with the rate of urbanisation. Equipment in the water provision system is dilapidated as a result of old age. At the time of the study, it was not unusual to hear that rapid sand filters were not functional and many more were either decommissioned due to old age, or were in a bad state of 
disrepair. The pumps equipment at various plants has outlived the efficiency of their designs.

Urban councils are incurring huge maintenance costs to keep them functioning. Tower pump stations at the water works only have few working pumps, whilst a number of them are now obsolete. The same goes for the vertical turbine pumps, which have also outlived their usefulness. Due to obsolete equipment, water treatment plants are producing less amounts of water than they are capable of producing. In Harare for example, only one out of at least four plants is functional and is supposed to supply water to an estimated 2.8 million Greater Harare residents with growth rate of 5.8\%(www.voanews.com/zimbabwe/news, 14February,2012; http://www.radiovo p.com,4 March,2012). Harare's water supply system was built in 1956 for 25000 people just about a tenth of its now ballooned population .The existing urbanrelated laws and policies provide for centralised institutions and procedures that appear ill-adapted to the challenges.

The most telling paradox of cities' water crisis is that it is not entirely lack of water. The problem is distribution, hampered by feeble infrastructure and lack of resources. The water pipe networks remain a punctuated mess and are in such disrepair. Extensive leakages and pipe bursts along the main pipe lines that supply water to the towns from the water works were a common sight and featured prominently in council reports. Water bursts were also being experienced in the old reticulation mains feeding the residential areas. Engineers revealed that the water system had several underground leakages and a small leak was estimated to put to waste 500,000 litres of water per year. These were all attributed to the age of the pipes. The aging equipment was compromising the efficiency of the water supply. This may result in the loss of huge amounts of expensively treated water. Even where they are functioning, they do not have the capacity to meet increasing demand. It is ironic that while ZINWA reports that major dams are full, with most spilling, we continue to experience water cuts.

According to Marcy (1999) unaccounted for water for Bulawayo could be as high as $17.5 \%-40 \%$ of total produced water. The reasons for this high unaccounted for water is possibly due to meter registration and meter reading errors. Indeed water bills are at times based on estimates. Leakage control is almost non-existent in most urban centres, it being based on one person patrols yet water pipeline networks are quite extensive(Bulawayo- $21 \mathrm{~km}:$ Harare-40km). Bulk metres, whether functioning or not are being read although it appears as if data is not being analysed to spot irregularities. Municipalities should try and control pressures through strategic placement of pressure reducing valves. Also there is need for the full metering of all consumers. 
Water reticulation and sewage systems were designed for far fewer residents and since then, nothing has been done to cater for the swelling populations. Sewer systems are no longer intact and badly and urgently need upgrading. Lack of essential spare parts, tools, equipment and technical expertise to carry out maintenance has left the water supply network in a terrible state of disrepair. Recent high levels of staff turnover at different levels of the water institutions have aggravated the situation. Despite the euphoria and optimism that followed the formation of the Inclusive Government, service delivery remains woefully inadequate and a distant dream for a vast majority.

It is apparent that urban areas or parts thereof, go without water for long periods. Therefore, over 4000000 people face the risk of water-borne diseases more so with the impending United Nations agencies' withdrawal of funding for water purification in thirty four (34) urban centres after a three-year partnership (www.voanews.com/zimbabwe/news/14February,2012; The Herald, 3 February, 2012; http://www.dailynews.co.zw, 24 February,2012). Because water is such a vital resource, people cannot do without it so they resort to fetching this precious and priceless commodity from unprotected and thus unsafe sources (See Plate 1).It is not unusual to see people sourcing and using untreated and therefore unsafe water which exposes them to water-borne diseases such as cholera and typhoid. This disease easily spread to the country's other densely populated centres, especially towns as they are communicable and highly contagious.

\subsection{Rapid urbanisation}

Since the late 1990s, a number of countries in the Third World in general and Southern Africa in particular, have experienced economic hardships. Coupled with droughts, these have forced several people to migrate into the urban centres, explaining the phenomenal urbanisation. The high density suburbs of these urban centres have more people than they can accommodate as a result of the unplanned urbanisation. Every time there is a drought in Zimbabwe, a great deal of migration from rural to urban areas occurs as migrants head for towns nearest to their rural areas and settle there as best as circumstances permit. The same migratory movement occurs also whenever there are political disturbances caused by factors such as disputed election results or intermittent civil wars in the region and beyond.

Another major cause of this trend is a social one, education in its two stages, first its acquisition, which is relatively easier in urban areas because of the abundance of its dispensers and centres and second when those who have received it want to apply or use it practically (economic development in urban areas). After acquiring whatever education, people prefer remaining in the urban centres. 
Officially as well, high, medium and low density areas are also growing, thus pilling pressure on the water delivery systems which are at best in the intensive care unit. Due to the increase in the population, urban centres are unable to manage their domestic water efficiently. The cities have varying storage capacities and daily demands for water. For Harare daily demand stands at 1200 mega litres vis a vis the daily pumped 640 mega litres (The Zimbabwean, 24 February, 2012). Under normal circumstances, the storage tanks should hold supplies for not less than three or four days. The demand therefore, means that at any given time the tanks are not full as all water that is produced is consumed directly with no water stored for a balancing effect. City engineers' departments revealed that during peak periods, the cities experience water shortfalls. The areas that get worst affected are the high densities and those situated on high ground. A study by Mangizvo and Kapumbu (2010) shows that the city of Kadoma's water demand was at $31000 \mathrm{~m} 3 /$ day with a peak of $46,500 \mathrm{~m} 3 /$ day. The city's engineering department projected a future demand of $60,000 \mathrm{~m} 3 /$ day by the year 2015 thus pilling pressure on a water delivery system that is already under siege. Estimates suggest that the country's urbanisation rate ranges between $2.29 \%$ (estimates for 2005-2010) and 3.4\% (projection for 2010-2015) per annum (http: //www.indexmindi.com.) This is only an estimated national average, there are numerous variations in these rates, them being a function of a number of variables, town size being one of them. Municipal estimates, at the time the study was conducted, showed that the populations of the urban centres had increased quite significantly. Table 2 summarises ballooning urbanization trends in the country with a specific focus on the ten largest towns and cities. In fact, the figures could even be much higher. The towns, particularly the largest ones, are experiencing phenomenal urbanization rates, which results in an increasing demand for domestic water. Urbanisation is becoming increasingly difficult to manage as municipalities restrict new informal settlements. The net effect of restriction is that you squeeze people into existing settlements and then you have the backyard shack phenomenon. The effect has created very difficult conditions to live in. In Zimbabwe, this phenomenon had become particularly express in the major cities notably Harare, Bulawayo and Chitungwiza. It thus becomes imperative, instructive, and mandatory to reflect on service delivery in urban areas given such a scenario (See Table 2). Councils are failing to address the social determinants leading to diarrhoeal disease as evidenced by their appeal for central government's intervention to holistically arrest the crisis. 
Table 2: Population Changes in Zimbabwe's Largest Cities/Towns

\begin{tabular}{|l|l|l|l|l|l|l|}
\hline & & Population & & & & \\
\hline Rank & City/Town & $\begin{array}{l}\text { Census } \\
1982\end{array}$ & $\begin{array}{l}\text { Census } \\
1992\end{array}$ & $\begin{array}{l}\text { Census } \\
2002\end{array}$ & $\begin{array}{l}\text { Estimate } \\
2007\end{array}$ & Province \\
\hline 1 & Harare & 656.011 & 1.189 .103 & 1.444 .534 & 1.607 .022 & Harare \\
\hline 2 & Bulawayo & 413.814 & 621.742 & 676.787 & 713.340 & Bulawayo \\
\hline 3 & Chitungwiza & 172.556 & 274.912 & 321.782 & 352.204 & Harare \\
\hline 4 & Mutare & 69.621 & 131.367 & 170.106 & 193.629 & Manicaland \\
\hline 5 & Gweru & 78.918 & 128.037 & 141.260 & 148.935 & Midlands \\
\hline 6 & Kwekwe & 47.607 & 75.425 & 93.072 & 103.210 & Midlands \\
\hline 7 & Kadoma & 44.613 & 67.750 & 76.173 & 81.008 & $\begin{array}{l}\text { Mashonaland } \\
\text { West }\end{array}$ \\
\hline 8 & Masvingo & 30.523 & 51.743 & 69.993 & 80.630 & Masvingo \\
\hline 9 & Chinhoyi & 24.322 & 43.054 & 56.794 & 65.109 & $\begin{array}{l}\text { Mashonaland } \\
\text { East }\end{array}$ \\
\hline 10 & Marondera & 19.971 & 39.384 & 52.283 & 60.291 & $\begin{array}{l}\text { Mashonaland } \\
\text { West }\end{array}$ \\
\hline
\end{tabular}

Source: Central Statistical Office, 2002; Population Reference Bureau, 2011.

Current interventions are reactive rather than proactive. This is not to say demand management is unnecessary, it should be the way to go since both local and national governments are working on shoe-string budgets. At the rate at which urban centres are expanding, they are likely to face even more acutely debilitating water problems. People are already battling everyday to get water and the situation in Greater Harare has reached crisis proportion as was the case with Bulawayo in 1993 and 2005,this because there is no investment in water supplies leading to demand outstripping supply. One wonders what problem there has been between the 1990s and today. Water supplies are being seriously rationed as if we were in a desert.

Water experts say that most African cities have not been able to develop the basic utilities for water and environmental services (solid waste disposal systems, sewage treatment, and industrial pollution control) to keep pace with the rapid growth and Zimbabwe is not an exception (Tsiko, 2007; Mangizvo and Kapungu, 2010).Incidentally, Southern Africa's, urbanization rates are among the highest in the world implying that insurmountable pressure is being exerted on water and its associated facilities (Garland \& Herzer, 2009; Makwara, 2011). High urbanization rates are increasing the demand for water for domestic consumption, power generation, industrial uses, and recreation (Chigumira and Mujere, 2009). There are several competing needs for water, for example the all-important agricultural 
sector, which ,up to about 2000 was the mainstay of Zimbabwe's economy and manufacturing industry.

Invariably, almost all of Zimbabwe's major urban centres are exhibiting water quality and scarcity problems and it is projected that these problems will worsen in the next five years (Nhapi, Siebel and Gijzen, 2008). Water quality in water courses is deteriorating because of regular inflows of poorly treated sewage effluents (Nhapi, Siebel and Dijzen, 2004; \&Magadza, 1997). At the same time, the quantity of water in both the water courses and reservoirs is also decreasing on account of massive siltation and eutrophication .Public toilets at congested rail and road termini and residential flats have been closed, forcing residents to defecate in the surrounding bushes. Worse still, Zimbabwe's major urban centres, due to poor planning are situated upstream of their water reservoirs' catchments. Such situations provide a conducive environment for the propagation of diseases. Under such circumstances, some of the highest levels of water-borne diseases get recorded resulting in unnecessary and avoidable deaths as alluded to earlier on (http://www.dailynews.co.zw). According to figures from Central Statistical Office (now Zimstats), Harare's population has swelled to 1400000 with a projected growth rate of $5.8 \%$ per annum, up from an estimated less than 1000 000 three years ago. Of Harare's 1.4 million people, 1.1 million come from high density suburbs, a figure too high compared to available space. It is evidently clear that the population growth is not relative to the space available. The situation is worse in most high density suburbs where residents are living in squalid conditions as a result of overpopulation. Choking under the weight of overcrowdedness amidst dilapidated infrastructure, relentless pressure is applied to towns' old reticulation systems, forcing cities like Harare to lose $25 \%-30 \%$ of treated water to burst pipes (http://www.dailynews.co.zw).

\subsection{Sources of Water}

Most urban centres draw their water from reservoirs that were constructed in the late 1930s up to the 1960s, well before the Zimbabwe attained independence. Then, there were strict controls on urbanisation (pass laws on permanent residence of blacks in towns) and towns were the exclusive preserve of the minority whites. The dams' use is no longer significant as they are highly polluted and silted implying not only higher water treatment costs but also reduced volumes of stored water. Harare's satellites (Epworth, Norton Ruwa \& partly Chitungwiza) are not even connected to sewage pipes. Open wells and sewers hem the narrow lanes of high density suburbs. Every alley carries their stench while canals are clogged with trash and sludge. Manyame river across which Lake Chivero is built, like Mucheke and Shakashe rivers in Masvingo, becomes a noxious black thread because of water hyacinth and sewage Harare's major source 
of water supply, testifies and epitomises this scenario. The towns' major water supply dams often hold a mere three months' supply of water. Suffice to say these reservoirs remain as the major sources of water for the much larger urban centres. Information from city engineers' departments, in concurrence with Zimbabwe National Water Authority's engineers indicates that the water systems were operating at far below their normal capacities, typically in the region of $40 \%$ $60 \%$.Present dams are no longer reliable to support the ever increasing population.

According to reports, Bulawayo is currently operating with a deficit of three (3) dams out of five (5) compounding its perennial water problems. Bulawayo's water problems have eluded resolution since they have been there ever since the town attained city status in 1943.In 1993, and 2005 Bulawayo got to the verge of closure owing to the crippling water shortage (http://www.timeslive.co.zw 19 February, 2012).The City's population presently hovers around +/_ 1000000 and it keeps on rapidly increasing yet its last water supply dam was commissioned in 1976, some 36 years back. The towns need a new dam every 10 years if their thirst is to be quenched.The problem of demand outstripping supply is compounded by the fact that water supply dams are heavily contaminated. A unique feature of Zimbabwe is that most of its major towns are located on watershed divides, which means that the water draining out of them flows into the drinking water sources, all of which are physically located downstream of these return flows. Due to poor planning, Greater Harare, Bulawayo, Gweru and Masvingo are all situated downstream of their drains meaning that water is drawn from contaminated catchments as it flows from the respective towns. As a way of mitigating the water shortage problem, boreholes have been sunk in all the urban centres. Sadly, borehole and well water is no longer safe for people to use without regular testing and treatment.

Sewage disposal has become a challenge to many local authorities which are struggling to repair burst sewer systems. Some councils (Harare, Chitungwiza, Masvingo, Epworth Norton and Ruwa) have discharged almost raw sewage into public waterways which even drain into their water supply dams. Harare has continued to pump 90 megalitres of raw sewage a day into Lake Chivero for lack of treatment capacity and Chitungwiza compounds the problem by releasing 60 megalitres of raw sewage a day into Lake Chivero resulting in huge water treatment costs yet the city's main sewage treatment plant at Firle can only process 54 megalitres of its normal 144 megalitres capacity (http://www.voanews.com 27,February,2012).Most boreholes have broken down owing to overuse by residents. Coupled with this, some companies have been and 
still are carelessly disposing of dangerous waste material into water courses, further compounding the already acute problem. This translates into increased water purification costs which visit the very people with any already compromised water supply. The Environmental Management Agency [EMA] has dragged Harare and Chitungwiza Town Councils and a few companies to court over the matter to no avail. According to the law, pollution beyond acceptable limits attracts a 5-year penalty. Clearly both the fines and sentences imposed are simply too low to be deterrent enough. UNICEF said the catastrophic 2008 cholera outbreak was a result of failure to access clean water by many households. Households accessed water from shallow wells for consumption after failing to secure water from the household taps (http://www.timeslive.co.zw 19 February, 2012).

\subsection{Infrastructure}

Most of Zimbabwe's urban areas have obsolete infrastructure. Urban councils are not able to provide services owing to aging pumps and motors. Typically, water treatment works are old and malfunctioning (The Standard, 2010). Residents, especially the poor, who normally reside in the high density suburbs, often go for long periods of time without water because the urban councils do not have the funds to replace the infrastructure. Even those in the low density areas are not spared from these water woes either. 'Serious valve' operations affect the delivery of water to the high-lying areas in towns and cities. When water flow weakens, high- lying areas are usually affected the most. This measure was put in place to speed up the complete restoration of water supply within the concerned towns. In Masvingo, a city which lies a stone's throw from the largest inland lake in Zimbabwe, thousands of residents have been plagued by erratic water supply. Water supplies are cut off quite regularly on a daily basis despite it lying close to this massive water impoundment. Worse still, the council does not pay for the raw water as per the will of MacDougall, the man who spearheaded Mutirikwi (Kyle) dam's construction. All the city council has to pay are Zimbabwe Electricity Supply Authority (ZESA) bills for power to abstract water from the reservoir.

According to numerous newspaper reports, some parts of Harare have not had water for periods exceeding two months and yet others have not had water running in the taps for over a year. This situation is going to continue unabated for an unknown period. The water distribution systems, built long before the country's independence, have gone without proper maintenance for many years. Pumps that have an expected lifespan of between 15 and 20 years have not been replaced since they were installed (Kwidini, 2007).

The situation is exacerbated by pumps and the water distribution pipe system that are having to contend with larger volumes of water that should be distributed so 
that water supply is commensurate with the ever increasing demand as urbanisation takes place (see Table 1). Since the water systems have seen better days, they continuously breakdown. This translates into water shortages. When provision and availability of water becomes inadequate, people are forced to use contaminated water, resulting in water-related diseases such as cholera and typhoid as they fetch water from unprotected sources and use the bush system as toilets are closed because of the non-availability of water (Dungumaro, 2007). Most city treatment works have parts, such as automatic valve actuators, which are out of commission. Delivery pipes and joints leak because of old age (The Standard, 2010). At the height of the cholera epidemic in 2008, Beit Bridge, a border town on the South African-Zimbabwe border experienced serious water problems as it failed to bring water from its water station to town as it did not have the parts to repair the pump. Its pump station could not pump water from the tower to the town as there were no spare parts to repair the pump.

As if this is not enough, cities cannot readily replace the broken down equipment as they are experiencing financial challenges. For example, the city of Gweru cannot afford to buy new motors and pumps as it is financially incapacitated. As a result, residents in the city go without water for more than twelve hours, daily (The Standard, 2010). Urban councils also suffer from the limited foreign currency resources. A severe shortage of foreign currency means service providers cannot maintain or replace aging equipment, or import water treatment chemicals, or electricity from neighbouring countries to keep waterworks functioning (Reuters, 2007).

Despite heavy rains which filled up city reservoirs in the 2005/6 rainy season, Bulawayo, Zimbabwe's second largest city, continued to experience water rationing and like in 1993, almost ground to a halt, as the city did not have foreign currency to purchase purification chemicals (Nhlanhla, 2008; The Chronicle, 2012).Low revenue levels also mean that the city cannot collect enough money to enable it to treat and deliver water to the residents (Nhlanhla, 2008). Consequently such technical problems mean that though there may be plentiful water in the reservoirs, it cannot be delivered for consumption in its raw state. Urban councils also lack autonomy in setting realistic tariffs, which would help them recover costs and ensure that they continue to operate effectively (Davison, 2001). They have to apply for permission from the central government to raise tariffs, which is often delayed by bureaucracy in government operations. As a result, local authorities are hindered in their day-to-day operations. Water shortages have had a number of negative impacts. They generally result in stringent water rationing, which further causes an increase in diseases as people are unable to bath or flush their toilets 
(Nyoni, 2007). Many resort to using the bush or open public places. The reduced water flow in the sewage system as a result of the water shortage causes frequent blockages in the system (Nel \& Berry, 1992). [See plates $2 \& 3$ below] This is a nuisance as bad odours engulf the affected areas and pools of sewage water cover the streets and open spaces, reducing children's playing space.

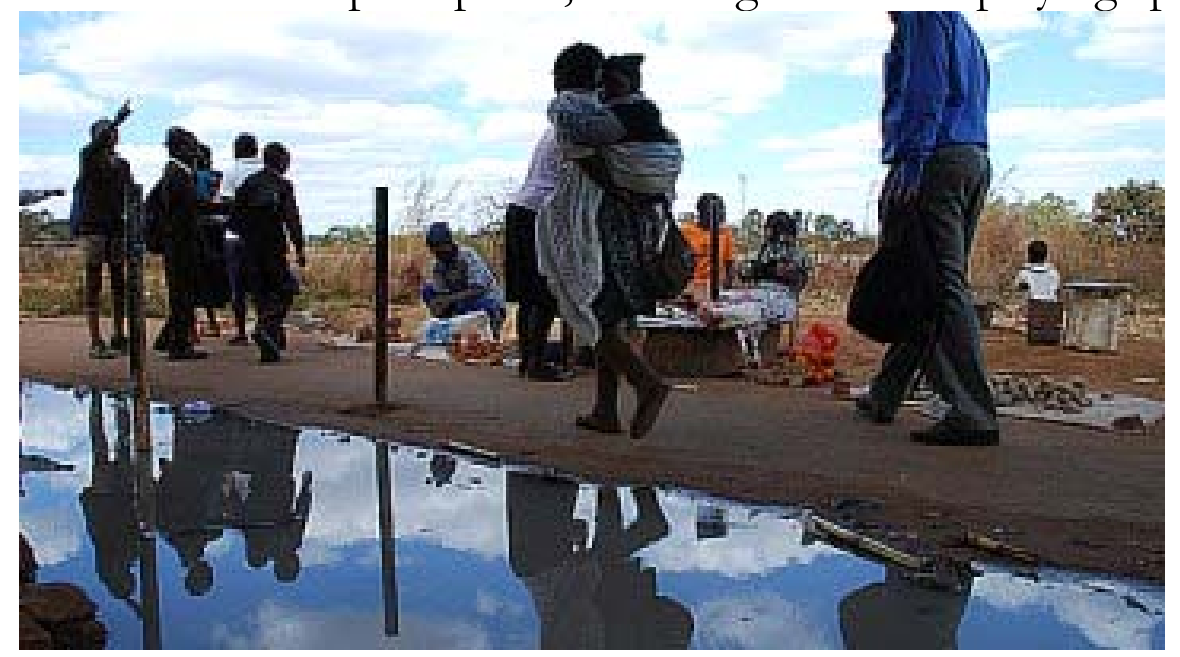

Plate 2: Residents of a Harare suburb walk past raw sewage Source: The Herald, 3 February, 2012

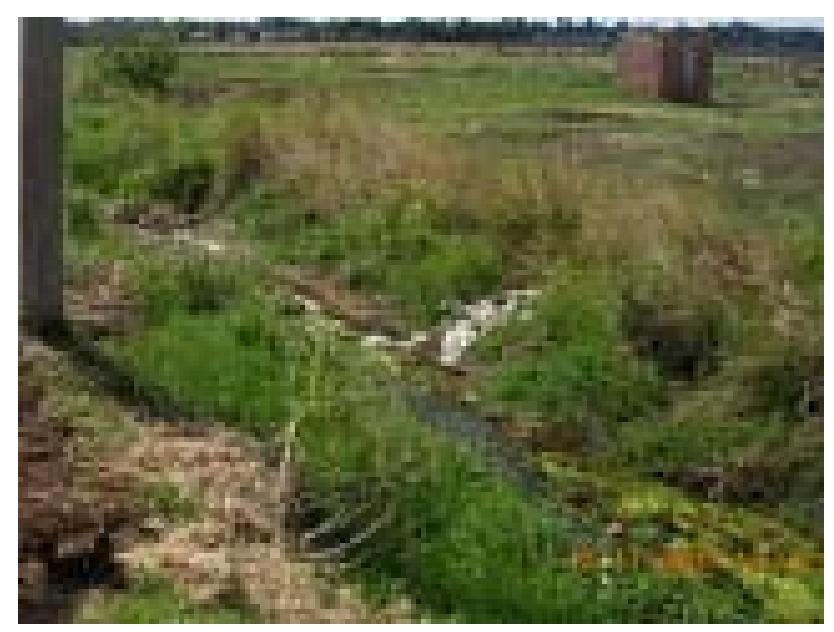

Plate 3: An open drain in a Harare township in 2004 Source: http://en.wikipedia.org/wiki/Zimbabwean cholera

By 2008, numerous such drains were carrying sewage from burst sewage pipes and faeces washed out of the neighbouring areas as the urban sanitation system collapsed. This aided the rapid spread of the cholera outbreak. The situation was aggravated by the collapse of the urban water supply, sanitation and garbage collection systems along with the onset of the rainy season leading to faeces with cholera bacteria getting washed into water sources especially public drains in addition to proving readily available nevertheless contaminated water. 
Harare ran short of purification chemicals culminating in the stoppage of delivery of piped water on 1 December 2008 (http://en.wikipedia.org/wiki/Zimbabwean_cholera_outbreak). By that date, many of its suburbs had not had any water supply for much longer. Harare's plight was replicated across Zimbabwe. Consequently, on 4 December 2008, a ministerial announcement saying there were only sufficient treatment chemicals in stock nationally for twelve weeks supply was made (http://en.wikipedia.org/wiki/Zimbabwean_cholera_outbreak). This meant that water shortages were becoming a regular occurrence in the bulk of the urban centres. Subsequently, some of these urban centres became epicentres of the worst cholera outbreak in the country's history which were attributed to the persistent water problems. There is always a potential for an outbreak of various diseases when sewage water flows all over and there is lack of access to safe water. Reports indicate that Harare alone pumps 90 megalitres of raw sewage daily into Lake Chivero for lack of treatment capacity (http://www.voanews.com 27, February 2012). The city's main sewage treatment plant at Firle is reportedly only able to process 54 megalitres of its normal 144 megalitres capacity. The city is thus releasing sewage into Greater Harare's water source thereby increasing the risk for the outbreaks of diseases. The problem is compounded by Chitungwiza town council which is releasing 60 megalitres of raw sewage a day into Lake Chivero resulting in huge water treatment costs (http://www.voanews.com 27, February 2012).Entire city sewage systems have collapsed hence diarrhoeal diseases are still an active concern. Systems were designed for far smaller populations than they have to contend with. Reticulation systems are out-dated and can no longer cope with the increasing population and thus cannot cope any longer and lots of cash are needed to maintain them. Many citizens are not putting their litter in dust bins yet municipalities do not have enough cash to remove the dirt .Consequently, citizens dump their litter willy-nilly resulting in the huge piles of dirt around the cities.Councils are now appealing for help at home by asking residents to pick up their litter .

With respect to water, there has been a cocktail of between eight and ten water treatment chemicals. Without doubt, this is quite expensive for the already financially crippled councils. Little wonder, municipalities have been grappling with water-borne diseases blamed largely on contaminated water since 2008 . The problem has worsened over the years with no solution seemingly in sight. A major contributing factor to the severity of the outbreaks is the collapse of Zimbabwe's public health system, declared a national emergency on 4 December 2008.(http://en.wikipedia.org/wiki/Zimbabwean_cholera_outbreak). 


\subsection{Power outages}

The severity of the water crisis in Zimbabwe is attributed to power outages affecting all urban centres in Zimbabwe. According to the various towns' engineering departments, this problem first reared its ugly face in Zimbabwe in 2005 and it is refusing to go. All municipalities cannot pump enough water as their operations are interrupted by power cuts. In the absence of power supply lines dedicated to water pumping, water treatment and pumping stations are severely affected, resulting in trickledown and backwash effect on water supply to the different residential areas. Zimbabwe has ever since then been experiencing serious power shortages, that have resulted in power cuts, which are negatively impacting on the supply of water. The magnitude of the problem has worsened in smaller urban centres as the water works could go for periods ranging from 6 hours to 18 hours on a daily basis without electricity. The Zimbabwe Electricity Supply Authority has not been able to dedicate a power line to the water pumps to avert water problems yet water is vital to life. Load shedding has been on the increase in the recent past. The situation has been exacerbated by numerous electrical faults that are attributed to aging electrical equipment and theft of cables and this has become a serious threat to water supply in many of Zimbabwe's urban centres. Typically, thieves strike when it will be least expected - during public holidays and in the middle of the night when electricity will be needed the most. Some of the thieves also steal transformer oil and this further compounds an already very bad situation.

\subsection{Loss of skilled manpower}

Zimbabwe experienced a massive exodus of skilled and semi-skilled manpower for greener pastures within and beyond the region. The harsh economic conditions that have prevailed in Zimbabwe from the late 1990s through to today are the main driving force in the loss of skilled manpower in the country. Inflation rose steadily and the buying power of many people was so eroded as to make it virtually impossible to use the Zimbabwe dollar. Under such circumstances, most of the skilled manpower left because they felt the remuneration they got was not commensurate with their worth. Most of them went to neighbouring countries where their skills were in great demand .These included engineers, health officers, plumbers and various other technicians. Semi-skilled and the unskilled labourers simply stopped reporting for work as they sought alternative sources of income aggravating the problem further. This happened mainly in 2008 and 2009. It meant that repairs went unattended to for long periods or that the work that was done was shoddy. The city engineers also claimed that some of the experienced workforce who had either retired or resigned had information on the existing 
infrastructure networks, which their replacements do not have, so problems such as burst pipes might have taken a long time to rectify.

5.8 Lack of political will

The political situation in Zimbabwe from about 2000 to date, not only complicated service delivery, it also grossly compromised it. Residents were of the view that the calibre of councillors in office lacked the vision to turn around the entire urban service delivery system, notably the pathetic water situation in the various municipalities. To them, most of the councillors were concerned with securing votes from their respective constituencies instead of ensuring that service delivery was improved in a wholesome manner. Here lies a problem which has plagued sub-Saharan Africa for so long; politics drives everything and everything is done for political expediency. The qualification for one to hold public office was patronage and 'bravado' rather than ability, skill or passion to serve the public. Ultimately, it is symptoms rather than the root causes of the problems that get addressed, meaning to say we expect to live with these problems for quite some time. Councillors need to be true servants of the people rather than being self-serving. Just like the national political leadership, local government leadership should be altruistic in its deeds and disposition. It defies logic for councillors to insist on their constituencies being attended to first, instead of having refurbishments of the water system being done according to priority based on some transparent criteria. In the context of the existing regime, a multiplicity of repairs gets undertaken at the same time, when it is clear that councils are thinly resourced. Newspaper reports indicate that instituted probes into the on-goings at local authorities show that, apart from the salaries ranging from US \$3 200 up to US $\$ 10000$, depending on the size of the urban council, for council managers, councillors were illegally granted loans. Interviews with residents revealed that councillors were allocating themselves loans using ratepayers' money instead of channelling it towards their needs. This reflects misplaced priorities, which only worsens the plight of the citizens. Water and sanitation should always receive priority attention.

According to some council officials, municipalities in Zimbabwe lack the autonomy in setting tariffs. This impact on their ability to ensure a full cost recovery of the services they offer. They depend on the central government for the funding of capital infrastructure projects, such as the laying of new water pipes and the construction of reservoir tanks. Apparently the central government itself is short of money and there is rampant corruption. There is evident lethargy and maladministration within government. This has severely debilitated urban councils in their quest to provide water, among other services, to their residents. All major projects must be approved by the central government. Problems that 
could be corrected early are left to worsen as municipalities wait for approval to buy parts and equipment. This red tape in the government does not help matters.

\subsection{Shortage of foreign currency}

It also emerged that urban water problems were partly due to the shortage of foreign currency. Municipalities could not raise their own foreign currency, so they depended on the Reserve Bank of Zimbabwe. The central bank was, however, burdened with other responsibilities, such as procuring much needed food for the country which has been experiencing recurrent droughts besides being subjected to bad agricultural policies. Councils could not and cannot raise foreign currency from ratepayers, as during that time, the Zimbabwe dollar was the official currency. Foreign currency was necessary for importing spare parts as well as water treatment chemicals. At the time of the study, the political turmoil prevailing in Zimbabwe made it difficult for municipalities to import spares. The country was under targeted sanctions and all municipalities fell in this bracket. Urban councils could not import spares from Europe. The water system in place had most of its components originating from Britain, the former colonial power. The only way out is to lay new systems which is impossible as municipal councils do not have adequate funds to undertake such an activity. Be that as it may, priority attention should and must be given to sourcing and providing funds for this very crucial area.

\subsection{Conclusions}

Many urban settlements in Zimbabwe are experiencing acutely debilitating service delivery challenges. Among these are a myriad of water problems that continue to dogg most of them. This plethora of water problems is seemingly eluding resolution as is evidenced by their refusal to go. Apparently water problems are more pronounced in the larger settlements. Not surprisingly, Greater Harare is hardest hit with areas that were previously not affected now getting water cuts including the leafy, posh and upmarket suburbs. The causes and impacts of these problems are multifaceted in their nature .By and large, these water problems revolve around quality and quantity issues, both of which recur and resonate across the country. Such a scenario does not augur well for the densely populated urban centres as it can easily translate into serious environmental, ecosystem and human health problems which may degenerate into a catastrophe as was the case in 2008 when the worst cholera outbreak in the country's modern history assumed epidemic proportions.

The water shortages are exacerbated by the shortage of foreign currency to buy water treatment chemicals and spare parts for the dilapidated and decaying water distribution networks and power cuts that have hit the nation. This necessarily 
implies that residents get short-changed as they get supplied with both grossly reduced and under-treated and under-purified water, if they are lucky to have water running through their taps. There are fears of cholera outbreaks as the situation seems to be eluding resolution and getting out of hand. In the case study urban settlements, residents continue to be dogged by water problems as typhoid is spreading. It is evident that the explosion of urban populations in poorer countries is too fast for municipalities to keep up. National access to safe water in Zimbabwe's urban areas has significantly declined, particularly between 2006 and 2008.

At the height of the problem, people literally slept in queues and travelled long distances around their respective towns in search of this all-important and yet priceless commodity. Quite often, residents collected water from nearby burst pipes, wells, boreholes and streams. A source which separates the delivery of drinking water from potential contamination, such as piped supply, protected well or spring is deemed to be 'safe'. Interpretation of access varies between countries but generally it refers to a household supply of 20 litres that can be fetched within a 30-minute round trip, a distance of about one kilometre. Simple low cost and low maintenance technologies are now available to fulfil these undemanding criteria. Yet a lot of people are still being forced to gamble their health and lives with unsafe drinking water. 'Safe' sanitation is as a facility which removes excreta from the risk of human contact and encompasses covered pit latrines as well as flush toilets. The sanitation target should be the Cinderella of the cause, and rightfully should receive funding for both water and sanitation programmes across the country. It is incomprehensible that more Zimbabweans have access to mobile phones than toilets a scenario which obtains in most developing countries even some which are boasting nuclear weapons and space programmes. The notion that diarrhoea is caused by drinking contaminated water presents an incomplete picture. More attention should now be given to the link with unsafe sanitation and absence of hand washing. There ought to be safe and clean drinking water and sanitation as a human right that is essential for the full enjoyment of life and all human rights. The best way to overcome all this lethargy is Sanitation and Water for All. There too is need to gain a greater understanding of the link between water, sanitation and economic growth, in order to commit appropriate resources.

There has to be greater determination in convincing households of the value of safe sanitation and improved hygiene. Promising results have been achieved in an approach known as community- led sanitation preferably using participatory methods which promote behaviour change through peer group condemnation of open defecation as an anti-social habit. Creating a sense of ownership within 
community-level water and sanitation projects in both rural and urban areas has a consistent record of success. An improved understanding of the right to water could translate into wider citizenship movements to bring local and national governments to account.

Under pressure from rising populations and more extravagant lifestyles, water has become a scarce resource. Inevitably, it is the poor who tend to lose out in competition for resources, typically through the pricing mechanism. Many residents are over-extracting freshwater from vital aquifers faster than its natural rate of replenishment, causing groundwater tables to fall dramatically. Nowhere in Zimbabwe is the need for demand management more acute than in the capital and its environs. Appropriate measures include awareness programmes, water pricing, and pollution prevention, rationing and reusing water and recycling wastewater. The impact of water shortage has resonance on drinking water sources which need to be more resilient to variable rainfall.

Provision of water is still a challenge. The problem of water supply in the various cities of the country has had very serious consequences, especially in the years 2008 and 2009. During the worst cholera epidemic in Zimbabwe's history, towns were considered high-risk areas for cholera because of the on-going water and sanitation problems (Medecins Sans Frontiers, 2009). Between November 14, 2008 and April 4, 2009, well over 1500 deaths were recorded across the country and most of the deaths were reported in areas such as the high density suburbs that were characterized by water shortages and poor sanitation (World Health Organisation, 2009).Prior to the cholera epidemic, urban centres such as Beit Bridge, Chitungwiza and Kadoma were in the news regarding cases of deaths attributed to the lack of safe drinking water.

Council medical staff reported a high incidence of water- borne diseases. They said these were prevalent among young children who played in the sewagepolluted water. They also drank water from unprotected sources. Due to the scarcity of domestic water, residents have dug shallow wells from which they draw water for various uses. These wells, instead of bringing relief to the residents, have become a health hazard. Most of the wells are not protected, hence runoff after storms collected in them. Given that Beit Bridge, Bindura, Bulawayo, Greater Harare, Gweru, Kadoma, Masvingo and Mutare, among other Zimbabwean urban centres, have experienced serious sewage bursts, raw sewage has found its way into some of the wells. As a result, deaths attributed to diarrhoea have been recorded. Information given by the health staff in municipal councils showed that most ailments treated in council clinics were water-related. These towns have also experienced serious water rationing as a way to balance the sharing of this limited resource among all the suburbs in the various towns, bringing a great inconvenience to residents. Almost all suburbs in the various towns have 
experienced serious sewage blockages. This was due to the reduced water flow in the system, which presented great potential for disease outbreak.

The shortage of water has resulted in the spread of water-borne diseases in addition to causing discomfort to householders and several blockages in the sewage systems. Undoubtedly it is a serious threat to sustainable urban development in the country. The economic situation is threatened as industries do not have water for production purposes. Socially the health of the residents is under siege. The environment is polluted as toilets cannot function well without water. It is imperative to turn around the situation in order to avert any further outbreak and spread of diseases in the country. Regrettably, Harare and its environs continue to be hit by a biting water shortage to the extent that another epidemic is looming as evidenced by the current typhoid scourge reported by the City's Health Department yet water shortages are still prevalent (The Sunday Mail, 27 November, 2011). The persistent crippling water shortage results in many households resorting to unprotected water sources for domestic consumption. Tap water could not help the situation because when it flows, it is said to be unsafe thereby exposing residents to and precipitating further spread of waterborne diseases. Municipalities are failing to produce enough water to meet demand. In some cases, the situation gets compounded by councils' water disconnections to residents who are defaulting payment for various services rendered.

\subsection{Wither Zimbabwe?}

\subsection{General recommendations}

Zimbabwe remains at the risk of another major outbreak of waterborne diseases because the same problems that helped drive the last cholera epidemic remain unresolved. The Ministry of Health should urgently seek financial bail-out from Treasury to control disease outbreaks countrywide to avoid the unnecessary loss of life, particularly because these pandemics arise from water problems and poor sanitation facilities in the country.

There is a desperately urgent need to look into service delivery issues in the country's urban areas. Water is vital element in human survival. There is a compelling need to come up with long-lasting solutions to the problem of the water shortages. To cope with rapid urbanisation, local and national settlement planners have to look into the future from the usual three perspectives: short, medium and long term.

The need for residents to engage service providers on water supply and sanitation improvement cannot be overemphasised. Engagement should remain a key 
strategy in responding to problems faced by the residents. Comprehensive plans with time frames should be in place to address water shortages-e.g. rehabilitating existing water infrastructure and the construction of new water supply dams. Residents' representatives should win the hearts and minds of residents by working towards achieving measurable results like improvement in water supplies and sewage reticulation.

Water provision should receive priority attention from government. It is a national crisis which needs a national solution because councils alone cannot find ways of providing potable water facilities as an alternative. We contend that the causes of cholera have not yet been dealt with and failure to do that means that we won't win the typhoid war. Urban residents should look for permanent solutions to the outbreaks in their midst and take responsibility in monitoring cleanliness within their communities.

There is need to conduct some monitoring and evaluation of water and sanitation interventions in urban areas. This is important because if all of the leakages are detected early, councils can quickly review any strategy in place to see if it is sustainable. This will save water loss through leakages and burst pipes, while, at the same time, ensuring that citizens get the best service possible. It is imperative for urban councils to attend to leak detection, unsuitable pressures, and inadequate maintenance in these old reticulation systems. Furthermore, budgets, lack of resolve and drilling boreholes should receive priority attention

\subsection{Refurbishment of the water system}

Urban councils must give priority attention to the refurbishment of their fatigued yet overstretched water systems to avert the resurgence of the diseases. This is important as access to clean water is essential in ensuring human well being. In 2000, the United Nations committed itself to attaining one of the Millennium Development Goals, which seeks to halve, by 2015, the percentage of people living without sustainable access to drinking water. This requires that councils adopt new technologies with ready spares and better efficiency, instead of the old equipment installed in the late 1930s through to the 1950s. The old water supply networks are being overworked and overstretched hence they are readily yielding to the relentlessly excessive pressure they are subjected to. It is a lot more costly to repair them than to actually replace them.

\subsection{Political will to tackle the problem}

The government of Zimbabwe should cede autonomy to set water tariffs to local authorities. This will capacitate them to recover costs as well as embark on new projects in service delivery without going through the red tape in government. This way, residents will get the water they so desperately need. Resources should 
be channelled towards the improvement of water supplies. Councillors need to get their act together and have their priorities right. Elected office bearers should be altruists, true servants of the people rather than being self-serving. There is need for ethical considerations in council activities so that they do not get guided by the 'what is in it for me philosophy'. Elected representatives should be accountable to their constituencies and conduct constituency business in a transparent manner. The government, both national and local has the traditional responsibility to provide water and other important facilities and services to these sprouting communities. The above scenario is based on the sound assumption that it is impossible to stem the exodus from the rural areas to urban centres. To cope with this fast urbanisation development local and national settlement planners have to look into the future.

\subsection{Involvement of the community}

There has always been a top-down approach in the provision of services in Zimbabwe's urban centres. It is now imperative, instructive and mandatory to change this operating modus operandi. The community should always be involved by way of informing them on water problems and educating them on conservation measures and on sustainable utilization of water. They should feel that they are part of the system as they suffer the consequences of water shortages. That sense of ownership engenders responsible and sustainable water utilisation and mutual trust between residents and the council will get enhanced.

Actively involving the community before even thinking about building more storage facilities could go a long way in an attempt to provide a long- lasting if not permanent solution to the water problem in the country. Perhaps the starting point could be educating people on not only the value of water but also the purification and distribution processes. This way people will appreciate the challenges faced by their respective councils and they can even proffer solutions. Given that so many brains, instead of only a few will be involved in the water equation, it reasons out that more workable solutions could realistically be proffered.

\subsection{Increasing storage capacity}

There is need to construct larger storage reservoirs in all the urban centres so that, at any given time, there is water in the storage tanks. This will offset deficits during the dry climatic seasons. This is the most logical thing to do in light of the fact that the country is rapidly urbanising. The process of urbanization is largely happening in the form of the growth and expansion of existing urban centres .This strains and stresses existing facilities and services as insurmountable pressure 
is constantly exerted on old water distribution networks which have seen better days.

\subsection{Develop new cost-effective water resources management strategies}

Most, if not all the urban councils in the country need to complement the available sources of water. The existing water resources infrastructure is already overstretched and the meteoric urban population growth is pilling pressure on them. In the past, the increase in water demand has invariably been partially addressed by infrastructure improvements to increase supply, typically paid for by government budget and donor funding. However, this solution is no longer sustainable. There is a cost-effective alternative that has been gaining prominence: the more efficient use of water resources. Rather than increasing supply, unreasonable demand can be decreased relieving supply demand faced by water utilities and government agencies. Water conservation (demand management) focuses on long-term water savings. Water conservation takes various forms such as water rationing, metering of usage, re-use, lining of conveyance and storage systems. This should be appreciated against the background that Zimbabwe's urban centres are exploding, with population doubling every 20-30 years. Greater Harare for example is teeming with people. This increasing population is exerting additional demands on water resources. Millions of dollars would be invested towards supply options but this will not be enough especially in the area of shrinking development aid and national budgets. So, demand, both present and future, must be reduced .This is where water conservation will play a role, it reduces unreasonable demand thus helping in copying with demand-supply imbalances. This strategy should be adopted as the last resort. Almost all urban centres in Zimbabwe have adopted this strategy in a bid to equitably distribute water to all its suburbs and industries. The problem is that there is no clear cut time table that is being followed in this endeavour. This kind of arrangement also applies to power supplies which aggravates water supply problems in the country. In addition, all waste water must be recovered and put it to good use. This water could be used for cooling purposes in industries or for watering gardens instead of letting it flow and pollute the environment, including the very sources of towns' water. In the long run, this is a sustainable way of utilizing water resources. Recycling of water can be introduced and where it already exists, it must be scaled up. Such physico-chemical water could be used to water parks, playing and sport fields or cemeteries through a two pipe system .It may as well be reclaimed to a portable standard. It is worth implementing conservation programme involving appropriate and conjunctive tariffs. When tariffs are high, they keep demand low. Demand curtailment by water conservation planners would typically be conducted for domestic, industrial, commercial, institutional and other water users. Reducing 
unaccounted for water involves specific measures such as leak detection and repair, block rate billing and reduction of water theft. Zimbabwe, just like the SADC region is known for recurrent droughts. Since water is critical to development, it is pertinent to come up with alternatives in the face of water shortages. This approach is however quite unattractive on account of the massive capital outlay that is required for the attendant infrastructure such as dams and pipelines to increase supply. Conservation is meant to curb demand and delay the implementation of the next water scheme. Indeed, conservation is more costeffective than supply augmentation. Little wonder, Bulawayo and Harare's water augmentation projects have been on hold for long periods of time, this despite the perennial acute water shortages in the country's two largest urban centres.

\subsection{New approaches to water resources management}

It seems rural life is healthier, happier, and more secure than urban existence provided water, energy, food and social amenities are both available and accessible. In light of this, emphasis ought to be on making life easily liveable in the rural areas by providing amenities. If we fail to do that, let us try and succeed to plan well ahead for a safe process of urbanisation that will cater for the social and economic needs of the increasing number of new urban residents most of whom live literally from hand to mouth. There is an urgent need to institute and take on board new water resources regimes and supply systems. Besides, there is need to educate water users on the value of water. In this regard, people should be made to realise that every drop of water counts, particularly that of treated and therefore safe water. Urban councils must reach out to residents in full force in order to get them to know that water does not come cheap and it comes at a premium price hence the need to use it wisely and sparingly. Perhaps, it is high time that urban councils seriously consider the correct pricing mechanism. This is only possible by full metering so that costs are associated with actual volume used. In most countries of the region, Zimbabwe included, water is treated using expensively imported chemicals using the very precious foreign currency which is hard to come by given the competing demands for the same foreign exchange from the various sectors of their economies which are in a bad state of repair and yet require to be diversified and expanded so as to generate the desperately needed employment. It needs no rocket scientist to appreciate that water is the lifeblood of every community, settlement and the economy at large.

It is prudent to establish a parallel system of raw water supply over and above the existing one, which could be used for domestic purposes other than drinking. Such water would be used for domestic uses like gardening, flushing toilet waste, washing clothes and cars. This could release and avail more treated and safe water 
to the consumers thus reducing the chances of water shortages. Such water may be abstracted from nearby sources since there are many streams and rivers which pass through or close by the urban centres that can serve this purpose. It is not expensive to do this because there would be no need for dam construction. All that is required is to invest in the water supply and distribution pipes. People would however have to be thoroughly educated about this kind of arrangement. Overall, the country needs to commit itself to turning around the situation.

There is need to raise consciousness and teach people about the spread, prevention and stopping diseases. Municipalities should find it better to concentrate on preventive measures rather than curative measures. Municipalities should rehabilitate and expand both the water and sewage reticulation systems so that they keep pace with the ever swelling populations.

It looks like some senior council officials lack competence in municipal management and have no capacity to handle environmental issues as evidenced by the release of raw sewage into the water proving poor planning, explaining why outbreaks continue. Municipalities should take full control of the management of water treatment. At national level, there is need to redouble efforts to rebuild the economy and restore basic services such as water supplies that had collapsed after years of neglect and underfunding. But the cash strapped administration has found it hard to undertake any meaningful reconstruction work after failing to get financial support from rich western nations that insist they want to see more political reforms before they can loosen their purse strings. So the national government should re-strategise in order to resource and capacitate itself to deal with the epidemic outbreaks which have demonstrated their propensity to rapidly spread across the country. Councils should reason with and pressure central the government to make to make it avails resources and for councils to inform residents of the risk of pandemics. Reasoning with government is the logical thing to do because the government is supposed to come in when there are problems that threaten the lives of citizens. It is high time people act as doctors in treating the government which seems to be suffering from a sickness that has perpetuated disease epidemics.

Urban councils on their part need to get their priorities right. The situation can be improved upon if the local authorities could acquire adjacent farms in order to expand towns and thus ease congestion a move that will subsequently make litter management easy. People should take pride in a clean environment and avoid throwing litter everywhere. They should adopt a green habit, at home and at work. We all need a clean environment hence let us take care of it in a sustainable way so that we can leave a heritage for the future generation .A new impetus for rethinking the laws and processes involved in delivering water in Zimbabwe's urban centres is urgently required. 
The outflow of all sewage treatment works should be tested, especially these days when it is supposed to be pure enough to be dumped into rivers. If there is a problem, we must fix it and if we could dump chlorine granules or some similar germ killer in the effluent while repairs are made so be it. Our towns and cities are modern, founded after Victorian engineers found the simplest way to prevent cholera and typhoid and similar diseases was to ensure that water supplies and sewage were kept separate. There is no excuse for us not doing so and letting the towns to be closer to the $19^{\text {th }}$ century urban area rather than modern and a progressive state. The most worrying outbreak of cholera, diarrhoea, dysentery and typhoid has occurred in the last few years when for over a century the country was free from epidemics-even when we had water rationing in the 1940s,1980s, and 1990s(due to severe droughts ), we were largely free of outbreaks. That more people live in towns is not a reason .Huge cities across the world do not lose control of public health simply because of a single city can house more people than live in Zimbabwe. People in the first decade of this century learnt to protect a well from runoff and that water from a dubious source should be boiled first before drinking it (The Herald, 31 January, 2012). Water supply problems in the first decade of this century were a contributory cause. Paradoxically, water supplies are a lot better than they were before the disease outbreaks started and a lot of work has been done to renovate the sewage works.

There is need to help improve access to clean water and ultimately prevent disease as was done by ICRC (Harare), World Vision (Bulawayo and Beit Bridge) and Action Faim (Masvingo) between 2008 and 2009. Essential water pumps, testing equipment and tools could be provided to local councils together with technical assistance and expertise to maintenance workshops serving plants and central water-distribution systems. There too is urgent need to support the rehabilitation of water systems with material and technical assistance. Ultimately the distribution network will require a complete overhaul to fully restore water supply to town residents. The initiative is a major boost to the authorities' efforts to rehabilitate central pumping stations. Keeping plants running could make all the difference to hundreds of families in the future. The Zimbabwean authorities face a mammoth task in rehabilitating the various plants. There is need for supporting improvements in Zimbabwe's water supply, because, among other things, this helps in curbing the spread of cholera. Residents should not mix service delivery issues with politics. There is need to report service delivery matters to council. Capacity building of residents' leaders to enable them to function well in their mandate should not be an option. 


\subsection{Public awareness campaigns}

Water pollution is a serious problem. Misconceptions that it does not exist should be corrected. Appropriate mechanisms should be established to check on the health of aquatic environments and effects of pollution on biota and human health. This means that water quality specialists and environmental engineers are needed. Skill should be developed through intensification, training and education. These people require adequate equipment for monitoring purposes. Vigorous public awareness campaigns to improve public water awareness should be conducted. All stakeholders should participate in tackling the water problems (government, individuals, private sector, interest groups and communities. Vigorous public awareness campaigns for improving the understanding of key issues at the political level should be promoted at national level and in the SADC region. Adequately equipped laboratories for monitoring purposes should be built in every province and these must network. Other important interventions include strengthening water management and aquatic ecosystems laws, implementing the polluter-pays principle, encouraging self-regulation, economic incentives, strengthening regulation and its implementation and promoting public participation in water resources planning and management. Water is a basic right and everyone has a role to play to enhance its value and the protection of river ecosystems. We should all think globally and act locally.

\subsection{Getting back to basics}

In the past there were a lot more checks on people handling food for sale to the public in stores and restaurants as they were regularly checked in surprise visits. There was a lot more enforcement of by- laws banning vending of prepared food. We need to bring back these levels of enforcement. We need more public lavatories, people must not be forced to defecate in open public places when caught short. Blair toilets along river banks and in other open areas will helpful to people who would be answering to nature's call. Keeping sewage out of water sources is essential. It should be remembered that these diseases are spread through contamination of streams, rivers and dams or contamination of food or hands with human waste of those who already have the disease. Stop contamination, particularly of water sources and you stop the diseases and incidentally at the same time eradicate bilharzia. We must be far more serious about ensuring that waste is not deliberately dumped in rivers nor accidentally washed into them by rainwater. 


\section{References}

Central Statistical Office (2002) Census 2002.Zimbabwe Preliminary Report. Harare: Government Printers.

Chatora, C. Taylor, P., \&Hoevenaars, J. P. M. (1995) Identification mission Mupfure catchment integrated water management. Identification paper on behalf of the Royal Netherlands Embassy, Harare, Zimbabwe.

Chaeruka, J. and Munzwa, K.(2009) Assessing Regulatory Framework Bottlenecks for Low-cost Housing in Zimbabwe. Final Draft Report, UN-HABITAT and the Government of Zimbabwe, Harare, June.2009

Chigumira, E. \&Mujere, N. (2009).Variability of urban water supply and demand. In J. Feyen, K. Shannon, \& M. Neville (Eds.), Water and Urban Development Paradigms: Towards an Integration of Engineering, Design and Management Approaches (pp. 431-434). London: CRC Press.

Davison, C.A. (2001). Urban Governance and the Effective Delivery and Management of Infrastructure Services in Urban areas in Zimbabwe: An Appraisal of Water and Sewerage Services Delivered in Ruwa. Urban Forum, 12(2), 139-170.

Dube, E. and van der Zaag (2002) Analysing water use patterns for water demand management: the case of the city of Masvingo. Paper presented at the $3^{\text {rd }}$ WRFSA/Water Net Symposium Arusha, 30-31 October, 2002.Integrating Water Supply and Water Demand for Sustainable Use of Water Resources.

Dungumaro, E.W.(2007) Socioeconomic Differentials and Availability of Domestic Water in South Africa. Physics and Chemistry of the Earth, 32, 1141-1147.

Garland,A.\&Herzer,L.(2009). Water for the Urban Poor: Integrated Solution. School of Advanced International Studies Review, 29(1).

Gumbo, B. \&Van der Zaag, P.(2002). Water losses and the political constraints to demand management: the case of the City of Mutare, Zimbabwe. WRFSA/Water Net Symposium Integrated Water Resources Management:Theory and Practice, Cape Town, 30-31 October, 2001. Physics and Chemistry of the Earth 27, 805-813.

House, J.M. \& Salt, B. 1983. Zimbabwe - A handbook. Mercury Press (P.) Ltd., Harare.

Hug, A. (2009). Inside Zimbabwe's Cholera Epidemic Canadian Medical Association. Retrieved from www.cmaj.ca , on December 15, 2008.

Kwidini, T. (2007) Water Shortage Looms in Harare. Mail and Guardian, Aug 01.

Magadza, C.H.D. (1997). Water pollution and catchment management in Lake Chivero. In: N.A.G. Moyo (Ed.), LakeChivero: a Polluted Lake. Harare: University of Zimbabwe Publications.

Makwara, E.C.(2011) "Water:An Economic or Social Good?Journal of Social Development in AfricaVol.26.2(Forthcoming)

Mangizvo, V. R. and Kapungu, N.(2010) "Urban Domestic Water Crisis in Zimbabwe: The case of Kadoma City "Journal of Sustainable Development in Africa,Vol12 No. 8,pp 254-263

Marcy P,(1999)Urban Water Demand management in Southern Africa.Sheladia Associates/SIDA,Harare

Medicins SansFrontieres (MSF). (2009). MSF Continues Work as Cholera Exceeds Worst-Case Scenario, January 30, 2009(accessed on 11 February 2009)

Mpande, R.L. \&Tawanda, M.(1998). Case Study: Southern Africa population dynamics and the emerging competition for water use in the Zambezi River Basin. In A. de Sherbinin \& V.Dompka (Eds.),Water and Population dynamics: case studies and policy implications. IUCN, PRB USAID and AAAS. 
Nel, E.L.\& Berry, B.B. (1992). The problems of supplying water to third world cities: Bulawayo's water crisis. Development Southern Africa, 9(4), 411-422.

Nhapi, I., Siebel, M.\& Gijzen, H.J. (2008). An inventory of the existing water management practices in Harare, Zimbabwe. Water and Environment Journal, 22 (1), 54-63.

Nhapi, M., Siebel, M. and Gijzen, H.J. (2004).The Impact of Urbanization on the Water Quality of Lake Chivero.Zimbabwe.Journal of the Chartered Institution of Water and Environmental Management, 18(1), 44-49.

Nhlanhla, J. (2008). Zimbabwe Water in Short Supply Despite Rain. Environment News Service (12 February).

Nyoni, M. (2007) Bulawayo Faces Water Crisis. Mail and Guardian (September 14-20).

Population Reference Bureau, 2011

Reuters (2007) Zimbabwe City Warns of Health Risks as it Cuts Water. Reuters (July 18).

Rondinelli, D.A. (1991). Asian urban development policies in the 1990s: From growth control to urban diffusion World Development 19 (7) 791-803

The Chronicle, 11 February, 2011

The Herald, 31 January, 2012

The Herald (22, January, 2010).Acute Water Shortages Hit Capital.

The Herald, 3 February, 2012

The Standard (16 January, 2010). Water Shortage Hits Gweru,

The Sunday Mail November 27, 2011) Another Epidemic looms.

The Sunday Mail, March 14, 2010 Probe Team Exposes Kadoma Corruption.

The Zimbabwean, Friday, 24 February, 2012

Tsiko, S. (2007) Zimbabwe: Water Quality Supplies Fast Deteriorating. The Herald.

United Nations/World Bank (2010) Water and Sanitation and the MDGs: Joint Monitoring Programme for Water Supply and Sanitation 2010 Update, United Nations/World Bank, New York.

World Health Organisation (2009). "Cholera in Zimbabwe - update 2". World Health Organization, 20 February 2009. Geneva, WHO.

http://en.wikipedia.org/wiki/Zimbabwean cholera outbreak http://geography.about.com/od/findmaps/ig/Country-Maps/Zimbabwe-Map.htm

http://www.radiovop.com 04 March 2012

http://www.thestandard.co.zw/ 04 March 2012

http://www.dailynews.co.zw 03 March 2012

http://www.swradioafrica.com 01 March 2012

http://www.zimonline.co.za 29 February 2012

http://www.voanews.com 28 February 2012

http://www.thestandard.co.zw27February2012

http://www.voanews.com 27 February, 2012

http://www.dailynews.co.zw 24 February, 2012

http://www.timeslive.co.zw 19 February, 2012

www.voanews.com/zimbabwe/news/ 14 February, 2012 